\title{
Kompetensi Guru dalam Meningkatkan Motivasi Belajar pada MTsn Pekan Heran Indragri Hulu
}

\author{
AS'ADUT TABI'IN \\ STAI Madinatun Najah Rengat, a2d.al.andalasi@gmail.com \\ No hp: 081252806937
}

\begin{abstract}
Abstrak : Pendidikan merupakan suatu proses tranformasi ilmu pengetahuan dari pendidik kepada peserta didik, agar ia memiliki sikap dan semangat yang tinggi dalam memahami dan menyadari kehidupannya sehingga terbentuk sikap ketakwaan, budi pekerti dan kepribadian yang luhur. Motivasi merupakan salah satu faktor yang dapat meningkatkan kualitas pembelajaran, karena peserta didik akan belajar dengan sungguh-sungguh apabila memiliki motivasi yang tinggi. Oleh karena itu, untuk meningkatkan kualitas pembelajaran, guru harus mampu membangkitkan motivasi belajar peserta didik sehingga dapat mencapai tujuan pembelajaran. Penelitian ini bermaksud untuk mengungkap bagaimana kompetensi guru dalam meningkatkan Motivasi belajar siswa di Madrasah Tsanawiyah Negeri Pekanheran, Kec. Rengat barat, Kab. Inhu Provinsi Riau. Penelitian ini menggunakan pendekatan kualitatif dengan rancangan studi kasus. Pengumpulan data dilakukan dengan teknik wawancara mendalam, pengamatan berpartisipasi, dan dokumentasi. Teknik analisis data meliputi reduksi data, penyajian data dan penarikan kesimpulan. Berdasarkan data yang diperoleh oleh peneliti baik melalui interview, observasi, dan dokumentasi maka dapat diambil sebuah kesimpulan bahwa Motivasi belajar siswa di MTsN Pekan Heran cukup baik karena dipengaruhi dengan adanya lingkungan yang baik. Hal ini terbukti dengan cukup antusiasnya siswa dalam mengikuti kegiatan-kegiatan yang diadakan sekolah Untuk menumbuhkan semangat belajar, ada beberapa cara yang dilakukan guru di MTsN Pekan Heran untuk menumbuhkan minat belajar yaitu: Memberikan hadiah, Melakukan pendekatan, Membesarkan semangat belajar, Mengarahkan kegiatan belajar, Memberikan pujian. Disamping itu, diketahui bahwa para guru yang mengajar di sini adalah mayoritas lulusan perguruan tinggi, ditambah dengan adanya fasilitas yang memadai sehingga para guru dapat lebih leluasa untuk melakukan kegiatan belajar mengajar secara maksimal. Selain itu, sekolah memberi kebebasan memilih stategi, metode, tehnik pembelajaran dan pengajaran yang paling efektif, sesuai dengan karakteristik mata pelajaran dan latar belakang pendidikan guru tersebut.
\end{abstract}

Kata Kunci : Kompetensi Guru, Motivasi, Motivasi Belajar

\section{PENDAHULUAN}

Dalam arti luas guru merupakan suatu profesi, yang artinya suatu jabatan atau pekerjaan yang memerlukan keahlian khusus sebagai guru (Uno, 2007: 15). Orang yang tidak memiliki keahlian untuk melakukan kegiatan yang hanya pandai berbicara dalam bidang-bidang tertentu, belum dapat disebut sebagai guru. Untuk menjadi guru, diperlukan syarat-syarat khusus, apalagi sebagai guru 
profesional yang harus menguasai betul seluk-beluk pendidikan dan pengajaran dengan berbagai ilmu pengetahuan lainnya, yang perlu dibina dan dikembangkan melalui masa pendidikan tertentu. Dan tugas guru sebagai profesi meliputi mendidik, mengajar, dan melatih bahwa peran guru di sekolah harus dapat menjadikan dirinya sebagai orang tua kedua (Usman, 2009: 5).

Pendidikan merupakan suatu proses tranformasi ilmu pengetahuan dari pendidik kepada peserta didik, agar ia memiliki sikap dan semangat yang tinggi dalam memahami dan menyadari kehidupannya sehingga terbentuk sikap ketakwaan, budi pekerti dan kepribadian yang luhur. Pendidikan boleh dilangsungkan dimana saja dan kapan saja. Sebagai proses, pendidikan menurut adanya penjenjangan dalam tranformasi ilmu pengetahuan, mulai dari pengetahuan ilmu yang dasar menuju pada pengetahuan yang sulit. Dan hal ini, tidak lepas dari peran guru, sebagai pendidik (rabbani) yang mempunyai andil sangat besar khususnya bagi pengembangan moralitas, spiritual, dan intelektualitas anak didik. Hal ini didukung dengan sebuah nasihat salah seorang sahabat nabi Ali bin Abi tholib r.a. yang menegaskan:"Didiklah anakanak kalian tidak seperti yang dididikkan kepada kalian sendiri. Oleh karena mereka itu diciptakan untuk generasi zaman yang berbeda dengan generasi zaman kalian."

Merujuk wacana di atas, maka jelaslah bahwa seorang guru harus memiliki kompetensi, yaitu pengetahuan, keterampilan, dan nilainilai dasar yang refleksinya dalam kebisaaan berfikir dan bertindak. Sebab kompetensi inilah yang juga akan menentukan keberhasilan anak didik dalam melaksanakan proses belajar mengajar.
Tentu saja hal ini tidak mudah diperoleh. Utamanya, yang berkolerasi dengan materi pelajaran yang diajarkan di sutau lembaga pendidikan (sekolah). Seorang guru tidak mungkin membidangi semua jenis mata pelajaran. Karena itu, kompetensi yang dimaksudkan untuk memenuhi kebutuhan pendidikan dewasa ini adalah dengan spesifikasi dari pengetahuan, keterampilan, dan sikap yang dimiliki seseorang serta penerapannya di dalam pekerjaan. Sesuai dengan standar kinerja yang dibutuhkan oleh lapangan. Maka kompetensi guru yang dimaksud memerlukan standarisasi agar dapat memberikan hasil yang memuaskan dalam proses balajar anak didik.

Undang-Undang Repuplik Indonesia Nomor 14 Tahun 2005 tentang Guru dan Dosen dijelaskan bahwa "kompetensi adalah seperangkat pengetahuan, keterampilan, dan perilaku yang harus dimiliki, di hayati, dan dikuasai oleh guru atau dosen dalam melaksanakan tugas keprofesionalan".

Sesuai hadits Nabi yang menyinggung masalah keahlian yang mutlak harus dimiliki oleh seorang guru sebagai orang yang diserai tugas untuk mendidik, yang artinya: "Dari $A b u$ Huroiroh RA Rasulullah SAW telah bersabda apabila sesuatu perkara (urusan) diserahkan pada orang yang bukan ahlinya, maka tunggulah kehancurannya" (Ismail, 1992: 55-56).

Kaitannya dengan motivasi, anak didik memerlukan kekuatan mental yang menjadi penggerak belajar. Kekuatan mental tersebut berupa keinginan, perhatian, kemauan atau cita-cita yang mempunyai tingkatantingkatan, baik rendah maupun tinggi. Ada tiga komponen utama dalam motivasi, yaitu : 1) Kebutuhan; 2) Dorongan; dan 3) Tujuan (Dimyati \& Mujiono, 2009: 80). 
Menurut Mc. Donald dalam motivasi adalah perubahan energi dalam diri (pribadi) seseorang yang ditandai dengan timbulnya perasaan dan reaksi untuk mencapai tujuan (dalam Hamalik, 2008: 158).

Sedangkan menurut Uno (2008: 1), motivasi adalah kekuatan baik dari dalam maupun dari luar yang mendorong seseorang untuk mencapai tujuan tertentu yang telah ditetapkan sebelumnya.

Dalam kegiatan belajar, maka motivasi dapat dikatakan sebagai keseluruhan daya penggerak di dalam diri siswa yang menimbulkan kegiatan belajar yang menjamin kelangsungan dalam kegiatan belajar dan yang menimbulkan arah pada kegiatan belajar, sehingga tujuan yang dikehendaki oleh subyek belajar itu dapat tercapai (Sardiman, 2008: 75).

Seorang anak didik yang memiliki buku yang lengkap, bersekolah dengan fasilitas yang memadai, belum tentu akan mendapatkan nilai yang baik dan memuaskan pada suatu mata pelajaran tertentu bila belum memiliki motivasi belajar dalam dirinya. Seorang anak didik yang lain mengalami hal serupa, yaitu nilai mata pelajaran di bidang tertentu tidak terlalu baik. Padahal ia memiliki waktu yang banyak untuk belajar. Kasus-kasus tersebut menunjukkan, betapa motivasi sangatlah penting untuk menunjang keberhasilan anak didik dalam proses belajarnya. Ada para ahli psikologi pendidikan yang menyebut kekuatan mental yang mendorong terjadinya belajar tersebut sebagai motivasi belajar. motivasi dipandang sebagai dorongan mental yang menggerakkan dan mengarahkan perilaku manusia, termasuk perilaku belajar. Dalam motivasi terkandung adanya keinginan yang mengaktifkan, menggerakkan, menyalurkan, dan mengarahkan sikap dan perilaku individu belajar (Dimyati \& Mujiono, 2009: 80).

Terjadinya motivasi belajar seorang anak didik salah satunya adalah berasal dari peran guru sebagai pendidik, pengajar dan pemberi contoh budi pekerti yang luhur. Seorang guru tentu menginginkan anak didiknya sukses dalam menempuh proses balajarnya. Strategi pembelajaran yang dilakukan seorang guru juga bisa bermacam-macam dengan tujuan menumbuhkan motivasi belajar pada anak didik. Tidak kalah pentingnya, adalah kompetensi yang ada dalam diri seorang guru. Apabila seorang guru berkompeten di bidangnya, materi yang disampaikannya bisa jadi akan tetap dan memuaskan anak didik. Namun, itu saja belum cukup, performa guru yang tampak profesional bisa jadi akan mendorong anak didik untuk bercitacita berkemampuan seperti gurunya.

Motivasi merupakan salah satu faktor yang dapat meningkatkan kualitas pembelajaran, karena peserta didik akan belajar dengan sungguhsungguh apabila memiliki motivasi yang tinggi. Oleh karena itu, untuk meningkatkan kualitas pembelajaran, guru harus mampu membangkitkan motivasi belajar peserta didik sehingga dapat mencapai tujuan pembelajaran (Mulyasa, 2007: 58). Hal ini sesuai dengan apa yang disampaikan olek Ki Hajar Dewantoro dengan system among, " Ing Madyo Mangun Karso " artinya jika di tengah-tengah membangkitkan hasrat atau minat belajar peserta didik (Sardiman, 2008: 141).

Banyak sekali permasalahan dalam pendidikan, terutama dalam bidang proses pembelajaran, sebagian besar pendidik mengajar hanya memenuhi tuntutan lembaga formal saja, bahkan ada yang mengajar hanya mengharapkan gaji buta tanpa memperhatikan tujuan dari proses 
pendidikan. Berangkat dari sinilah penulis memilih MTsN Pekan Heran menjadi objek penelitian. Dalam hal ini, MTsN Pekan Heran Kecamatan Rengat Barat adalah salah satu lembaga pendidikan yang berada dalam naungan Kemenag Kabupaten Indragiri Hulu. Sekolah ini merupakan satu satunya sekolah Madrasah Tsanawiyah Negeri yang terkenal memiliki kredibilitas yang sangat bagus dalam pandangan masyarakat sekitar. Keberhasilan MTsN Pekan Heran ini tidak lepas dari peran guru yang berwawasan masa depan.

Disamping itu MTsN Pekan Heran merupakan lembaga yang mengalami perkembangan cukup pesat dan mampu bersaing dengan lembaga-lembaga pendidikan yang sederajad di Kabupaten Indragiri Hulu. Sehingga dipandang perlu untuk meningkatkan mutu dan kualitas guru kususnya dalam kompetensi, terlebih lagi guru sebagai pembimbing dan yang mampu menjadikan peserta didik menjadi manusia yang berkualitas.

\section{Tinjauan Tentang Kompetensi Guru}

Kompetensi guru merupakan perpaduan antara kemampuan personal, keilmuan, teknologi, sosial dan spiritual yang secara kaffah membentuk kompetensi standar profesi guru, yang mencakup penguasaan materi, pemahaman terhadap peserta didik, pembelajaran yang mendidik, pengembangan pribadi dan profesionalisme (Mulyasa, 2007: 26).

Menurut Farida Sarimaya, Kompetensi guru merupakan seperangkat pegetahuan, keterampilan, dan perilaku yang harus dimiliki, dihayati, dikuasai, dan diwujudkan oleh guru dalam melaksanakan tugas keprofesionalannya (Sarimaya, 2008: 17). Heri Jauhar Muchtar mengatakan Kompetensi guru adalah segala kemampuan yang harus dimiliki oleh guru (persyaratan, sifat, kepribadian) sehingga dia dapat melaksanakan tugasnya dengan benar (Muchtar, 2005: 151). Di samping itu kompetensi guru (teacher competency) merupakan kemampuan seseorang dalam melaksanakan kewajiban-kewajiban secara bertanggung jawab dan layak (Usman, 2009: 14).

Di dalam agama Islam juga diterangkan bagaimana sikap yang harus dimiliki oleh seorang pendidik yaitu mempunyai kecerdasan secara menyeluruh (cerdas intelektual dan kepribadian) serta memberikan suri tauladan yang baik kepada peserta didik maupun masyarakat. Al-Ghozali mengatakan: Seseorang yang berilmu dan kemudian bekerja dengan ilmunya itu dialah yang bekerja di bidang pendidikan. Sesungguhnya ia telah memilih pekerjaan yang terhormat dan sangat penting, maka hendaknya ia memelihara adab dan sopan santun dalam tugasnya ini (Rosadi, 2002: 178).

Broke and Stone dalam Usman (2009: 14) mengatakan Kompetensi adalah gambaran hakikat kualitatif dari prilaku guru yang tampak sangat berarti. Dengan gambaran pengertian tersebut dapat disimpulkan bahwa kompetensi merupakan kemampuan dan kewenangan guru dalam melaksanakan profesi keguruannya.

Dalam undang-undang No:14 tahun 2005 tentang guru dan dosen bab IV pasal 10 ditegaskan bahwa untuk mampu melaksanakan tugas profesionalnya dengan baik, seorang guru harus memiliki empat kompetensi inti yakni : kompetensi pedagogik, kompetensi kepribadian, kompetensi sosial dan kompetensi profesional (Gintings, 2008: 12).

\section{Kompetensi Kepribadian}

Kompetensi kepribadian merupakan kemampuan personal yang mencerminkan kepribadian yang mantap, stabil, dewasa, arif, dan 
berwibawa, menjadi teladan bagi peserta didik, dan berahlak mulia.

Secara rinci sub kompetensi tersebut dapat dijabarkan sebagai berikut, yaitu: (1) Sub kompetensi kepribadian yang mantap dan stabil memiliki indikator esensial: Bertindak sesuai norma hukum, bertindak sesuai dengan norma sosial, bangga sebagai guru, dan memiliki konsistensi dalam bertindak sesuai dengan norma; (2) Sub kompetensi kepribadian yang dewasa memiliki indikator esensial: menampilkan kemandirian dalam bertindak sebagai pendidik dan memiliki etos kerja sebagai guru; (3) Sub kompetensi kepribadian yang arif memiliki indikator esensial:menampilkan tindakan yang didasarkan pada kemanfaatan peserta didik, sekolah, dan masyarakat serta menunjukkan keterbukaan dalam berpikir dan bertindak; (4) Sub kompetensi kepribadian yang berwibawa memiliki indikator esensial: memiliki perilaku yang berpengaruh positif terhadap peserta didik dan memiliki perilaku yang disegani; (5) Sub kompetensi akhlak mulia dan dapat menjadi teladan memiliki indikator esensial: bertindak sesuai dengan norma religius (iman dan taqwa, jujur, ikhlas, suka menolong), dan memiliki perilaku yang diteladani peserta didik; dan (6) Sub kompetensi evaluasi diri dan pengembangan diri memiliki indikator esensial : memiliki kemampuan untuk berintrospeksi, dan mampu mengembangkan potensi diri secara optimal.

\section{Kompetensi Pedagogik}

Kompetensi pedagogik meliputi pemahaman terhadap peserta didik, perancangan dan pelaksanaan pembelajaran, evaluasi hasil belajar, dan pengembangan peserta didik untuk mengaktualisasikan berbagai potensi yang dimilikinya.

Secara rinci setiap sub kompetensi dijabarkan menjadi indikator esensial sebagai berikut, yaitu: (1) Sub kompetensi memahami peserta didik secara mendalam memiliki indikator esensial: memahami peserta didik dengan memanfaatkan prinsip-prinsip perkembangan kognitif, memahami peserta didik dengan memanfaatkan prinsip-prinsip kepribadian, dan mengidentifikasi bekal ajar awal peserta didik; (2) Merancang pembelajaran, termasuk memahami landasan pendidikan untuk kepentingan pembelajaran. Sub kompetensi ini memiliki indikator esensial: memahami landasan kependidikan, menerapkan teori belajar dan pembelajaran, menentukan strategi pembelajaran berdasarkan karakteristik peserta didik, kompetensi yang ingin dicapai, dan materi ajar, serta menyusun rancangan pembelajaran berdasarkan strategi yang dipilih; (3) Sub kompetensi melaksanakan pembelajaran memiliki indikator esensial: menata latar (setting) pembelajaran, dan melaksnakan pembelajuaran yang kondusif; (4) Sub kompetensi merancang dan melaksanakan evaluasi pembelajaran memiliki indikator esensial: merancang dan melaksanakan evaluasi (assessment) proses dan hasil belajar secara berkesinambungan denga berbagai metode, menganalisis hasil evaluasi proses dan hasil belajar untuk menentukan tingkat ketuntasan belajar. Dan memanfaatkan hasil penilaian pembelajaran untuk perbaikan kualitas program pmbelajaran secara umum; dan (5) Sub kompetensi mengembangkan peserta didik untuk mengaktualisasikan berbagai potensinya, memiliki indikator esensial: memfasilitasi peserta didik untuk pegembangan berbagai potensi 
akademik, dan memfasilitasi peserta didik untuk mengembangkan berbagai potensi non akademik.

\section{Kompetensi Profesional}

\begin{tabular}{llr}
\multicolumn{2}{c}{ Kompetensi } & profesional \\
merupakan penguasan & materi \\
pembelajaran & secara luas dan
\end{tabular} mendalam, yang mencakup penguasan materi kurikulum mata pelajaran di sekolah dan substansi keilmuan yang menaungi materinya, serta penguasan terhadap struktur dan metodologi keilmuannya.

Setiap sub kompetensi tersebut memiliki indikator esensial sebagai berikut: (1) Sub kompetensi menguasai subtansi keilmuan yang terkait dengan bidang studi memiliki indikator esensial: memahami materi ajar yang ada dalam kurikulum sekolah, memahami struktur, konsep dan metode keilmuan yang menaungi koheren dengan materi ajar, memahami hubungan konsep antara mata pelajaran terkait, dan menerapkan konsep-konsep keilmuan dalam kehidupan sehari-hari; dan (2) Sub kompetensi menguasai struktur dan metode keilmuan memiliki indikator esensial: menguasai langkah-langkah penelitian dan kajian kritis untuk memperdalam pengetahuan/materi bidang studi secara profesional dalam konteks global.

\section{Kompetensi Sosial}

Kompetensi sosial merupakan kemampuan guru untuk berkomunikasi dan bergaul secara efektif dengan peserta didik, sesama pendidik, tenaga kependidikan, orang tua/wali peserta didik, dan masyarakat sekitar.

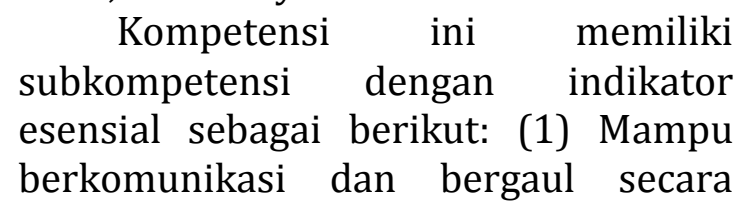

efektif dangan peserta didik. Subkompetensi ini memiliki indikator esensial : berkomunikasi secara efektif dengan peserta didik; (2) Mampu berkomunikasi dan bergaul secara efekif dangan sesama pendidik dan tenaga kependidikan; dan (3) Mampu berkomunikasi dan bergaul secara efektif dangan orang tua/wali peserta didik dan masyarakat sekitar.

Menurut M. Surya, dkk (2007: 423), macam-macam kompetensi yang harus dimiliki guru antara lain: (1) Kompetensi Intelektual. Sebagai seorang guru harus mempunyai perangkat pengetahuan yang ada dalam diri individu yang diperoleh untuk menunjang berbagai aspek unjuk kerja sebagai seorang guru profesional; (2) Kompetensi Pribadi. Perangkat perilaku yang berkaitan dengan kemampuan individu dalam mewujudkan dirinya sebagai pribadi yang mandiri untuk melakukan transformasi diri, identitas diri dan pemahaman diri; (3) Kompetensi Sosial. Perangkat perilaku tertentu yang merupakan dasar bagi pemahaman diri sebagai bagian yang tak terpisahkan dari lingkungan sosial serta tercapainya interaksi sosial secara objektif dan efisien; dan (4) Kompetensi Spiritual. Pemahaman, penghayatan, serta pengamalan kaidah-kaidah agama dalam berbagai aspek kehidupan.

Sedangkan menurut Johnson dalam Samsudin dan Budiman (2006: 38) ada 6 macam kompetensi guru antara lain: (1) Performance Component. Unsur kemampuan penampilan kinerja yang tampak sesuai dengan bidang profesi kependidikan; (2) Subject Component. Unsur kemampuan penguasaan bahan/subtansi pengetahuan yang relevan dengan bidang profesi kependidikan sebagai prasyarat bagi penanpilan komponen kinerjanya; (3) Profesional Component. Unsur kemampuan penguasaan subtansi pengetahuan dan keterampilan teknis 
profesi kependidikan sebagai prasyarat bagi penanpilan kinerjanya; (4) Proses Component. Unsur kemampuan penguasaan proses-proses mental mencakup berfikir (logis, kritis, rasional, kreatif) dalam pemecahan masalah, pembuatan keputusan dan sebagainya; (5) Adjusment Component. Unsur kemampuan penyesuaian dan penyesuaian diri berdasarkan karakteristik pribadi pendidik; (6) Attitudes Competent. Unsur komponen sikap, nilai, kepribadian pendidik.

Guru adalah salah satu komponen manusiawi dalam proses belajar mengajar, yang ikut berperan dalam usaha pembentukan sumber daya manusia yang potensial dibidang pembangunan, sehingga guru merupakan salah satu unsur di bidang kependidikan harus berperan serta secara aktif dan menempatkan kedudukan nya sebagai tenaga profesional, sesuai dengan tuntutan masyarakat yang semakin berkembang (Sardiman, 2008: 125). Guru yang profesional akan bekerja melaksanakan fungsi dan tujuan sekolah khususnya dan tujuan pendidikan umumnya, untuk itu ada ciri-ciri khusus yang harus dimiliki oleh guru.

Menurut Mulyasa (2007: 11), seorang guru dituntut memiliki minimal lima hal sebagai berikut: (1) Mempunyai komitmen pada peserta didik dalam proses belajar; (2) Menguasai secara mendalam bahan/mata pelajaran yang diajarkan serta cara mengajarkannya kepada peserta didik; (3) Bertanggung jawab memantau hasil belajar peserta didik melalui berbagai cara evaluasi; (4) Mampu berfikir sistematis tentang apa yang dilakukannya dan belajar dari pengalamannya; dan (5) Seyogyanya merupakan bagian masyarakat belajar dalam lingkungan profesinya.

Menurut Zakiyah Darojad (dalam Muchtar, 2005: 153 seorang guru harus mempunyai ciri-ciri sebagai berikut, yaitu: (1) Kegairahan dan kesediaan murid untuk belajar; Membangkitkan minat murid ke arah yang baik; (3) Menumbuhkan sikap yang baik; (4) Mengatur proses pembelajaran dan mengatur pengalaman belajar serta kegiatankegiatan yang berhubungan dengannya; dan (5) Mengerti dasar-dasar yang memungkinkan terjadinya perpindahan pengaruh belajar ke dalam kehidupan di luar sekolah.

Menurut Hadari Nawawi seorang pendidik akan mampu menjalankan tugasnya apabila mempunyai ciri-ciri sebagai berikut (Rosadi, 2002: 185187):

\section{Berwibawa}

Wibawa disini diartikan sebagai sikap atau penampilan yang dapat menimbulkan rasa segan dan hormat, sehingga anak didik merasa memperoleh pengayoman dan perlindungan. Kewibawaan bukan berarti harus takut kepada guru, melainkan siswa dapat taat dan patuh pada peraturan yang berlaku sesuai dengan apa yang dijelaskan oleh guru.

Hal ini sesuai dengan firman Allah dalam surat Al Furqon ayat 63 dan 75 yang berbunyi :

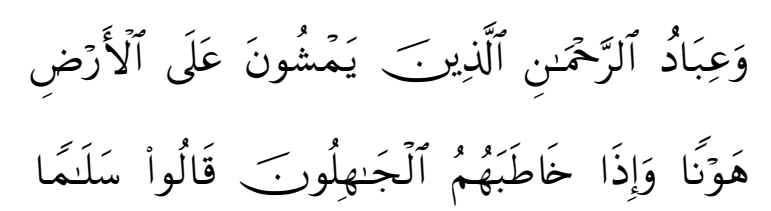

Artinya: "Dan hamba-hamba Tuhan yang Maha Pemurah ialah orang-orang yang berjalan diatas bumi dengan rendah hati, dan apabila orang-orang yang bodoh menyapa mereka, mereka mengucapkan kata-kata yang baik."(Al-Furqon, 25: 63). 


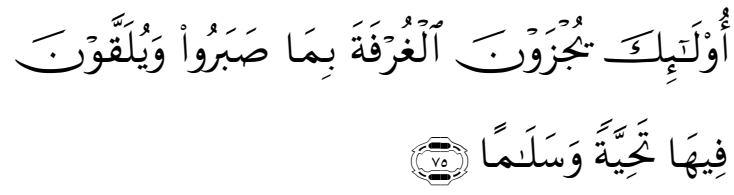

Artinya: " Mereka itulah orang-orang yang dibatasi dengan martabat yang tinggi (dalam surga) karena kesabaran mereka, dan mereka disambut dengan penghormatan dan ucapan selamat selamat didalamnya." (Al-Furqon, 25: 75)

Memiliki sikap ikhlas dan pengabdian

Memiliki sikap ikhlas dan pengabdian sebagai seorang guru dalam menjalankan tugas yang mulia harus ditanamkan pada hati menjalankan tugasnya dengan ikhlas dengan harapan menjalankan tugasnya haya sematamata ingin mengharap ridho Allah.

Sikap tulus dari hati yang rela berkorban untuk anak didik, yang diwarnai dengan kejujuran, keterbukaan dan kesabaran. Sikap tulus ini merupakan motivasi untuk melaksanakan pengabdian dalam mengemban peranan sebagai pendidik.

Sikap tulus ikhlas dan pengabdian yang harus ditampilkan setiap pendidik. Allah SWT berfirman:
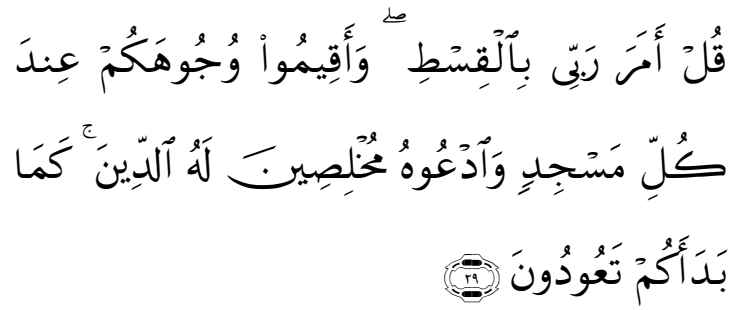

Artinya: "Katakanlah : Tuhanku menyuruh menjalankan keadilan, dan (katakanlah) luruskanlah muka (diri) mu disetiap shalat dan sembahlah Allah dengan mengikhlaskan ketaatanmu kepada-Nya, sebagai mana Dia telah menciptakan kamu pada permulaan (demikian pulalah) kamu akan kembali padanya." (AlA'rof, 7: 29)

\section{Keteladanan}

Rasulullah telah menunjukkan betapa pentingnya arti keteladanan. seorang guru bukan saja perkataannya yang dicontoh oleh siswa tetapi tingkah laku juga berpengaruh pada anak didik. Untuk itu guru sebaiknya memberi contoh yang baikbagi anak didiknya. Allah SWT berfirman:

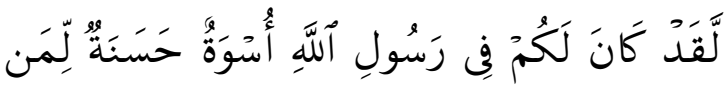

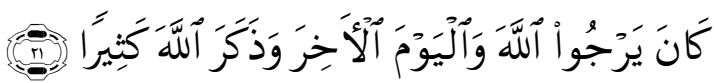

Artinya:" Sesungguhnya pada diri Rasululloh itu terdapat suri tauladan yang baik untuk kamu, bagi orang-orang yang mengharapkan rahmat Allah dan hari kemudian, dan yang banyak memuja Allah." (AlAhzab, 33: 21)

Perkembangan iptek yang harus disertai imtaq, semakin kompleksnya permasalahan hidup manusia, dan semakin majunya teknologi modern sangat membutuhkan figur guru yang mempunyai kompetensi di bidangnya. Menyadari begitu banyak pula permasalahan anak didik dalam menyongsong masa depan, maka masing-masing guru diharapkan dapat memenuhi standar kompetensi yang telah ditetapkan. Ini tidak lain adalah bertujuan untuk memberi layanan pendidikan yang sebaik-baiknya dan selayak-layaknya bagi anak didik.

\section{KONSEP TEORI \\ Pengertian Tentang Motivasi Belajar}

Menurut MC Donald motivasi adalah suatu perubahan energi dengan 
timbulnya efek dan reaksi untuk mencapai tujuan (Hamalik, 2008: 158). Sedangkan menurud Hamzah B. Uno, motivasi berasal dari kata motif yang dapat diartikan sebagai kekuatan yang terdapat dalam diri individu, yang menyebabkan induvidu tersebut bertindak atau berbuat. Jadi motivasi belajar adalah kekuatan atau tenaga yang dapat memberikan dorongan kepada kegiatan belajar murid (Uno, 2008: 3).

Perubahan energi dalam diri seseorang itu berbentuk suatu aktifitas nyata berupa kegiatan fisik, karena seseorang mempunyai tujuan tertentu dari aktifitasnya. Maka seseorang mempunyai motivasi yang kuat untuk mencapainya dengan segala upaya yang dapat dilakukan.

Dalam kegiatan belajar, maka motivasi belajar adalah keseluruhan daya penggerak di dalam diri siswa yang menimbulkan kegiatan belajar, yang menjamin kelangsungan dari kegiatan belajar dan yang memberikan arah pada kegiatan belajar, sehingga tujuan yang dikehendaki oleh subyek belajar itu dapat tercapai (Sardiman, 2008: 75).

Seseorang yang melakukan aktifitas belajar secara terus menerus tanpa motivasi dari luar dirinya merupakan motivasi intrinsik yang sangat penting dalam aktifitas belajar. Namun seseorang yang tidak mempunyai keinginan untuk belajar dalam dirinya merupakan motivasi ekstinsik yang diharapkan.

Oleh karena itu motivasi ekstinsik diperlukan bila motivasi intinsik tidak ada dalam diri seseorang sebagai subyek belajar.

\section{Macam-Macam Motivasi Motivasi Intrinsik.}

Bila seseorang telah memiliki motivasi intrinsik dalam dirinya maka ia secara sadar akan melakukan suatu kegiatan yang tidak memerlukan motivasi dari luar dirinya (Djamaroh, 1994: 35-36). Dalam aktifitas belajar motivasi intrinsik sangat diperlukan, terutama belajar sendiri, seseorang yang tidak memiliki motivasi intrinsik sulit sekali melakukan aktifitas belajar terus menerus.

Motivasi ini muncul karena membutuhkan sesuatu dari apa yang ia pelajarinya, bahwa anak didik yang memiliki motivasi intrinsik cenderung akan menjadi orang yang terdidik, berpengetahuan yang mempunyai keahlian dalam bidang tertentu. Jadi motivasi intrinsik muncul berdasarkan kesadaran dengan tujuan esensial, bukan sekedar atribut dan seremonial (Djamaroh, 1994: 35-36).

\section{Motivasi Ekstrinsik}

Motivasi ekstrinsik bukan berarti motivasi yang tidak diperlukan dan tidak baik dalam pendidikan. Berbagai macam cara bisa dilakukan agar anak didik termotivasi untuk belajar (Djamaroh, 1994: 37).

Oleh karena itu, guru harus bisa dan pandai mempergunakan motivasi ekstrinsik ini dengan akurat dan benar dalam langkah menunjang proses interaksi edukatif di kelas. Motivasi ekstrinsik tidak selalu buruk akibatnya, motivasi ekstrinsik sering digunakan karena bahan pelajaran kurang menarik perhatian anak didik atau karena sikap tertentu baik guru atau orang tua. Motivasi ekstrinsik yang positif maupun motivasi ekstrinsik yang negatif, samasama mempengaruhi sikap dan perilaku anak didik (Djamaroh, 1994: 40).

\section{Ciri-Ciri Motivasi Belajar}

Uno (2008: 10) berpendapat motivasi adalah dorongan internal dan eksternal dalam diri seseorang untuk mengadakan perubahan tingkah laku, 
yang mempunyai indikator sebagai berikut: (a) Adanya hasrat dan keinginan untuk melakukan kegiatan; (b) Adanya dorongan dan kebutuhan melakukan kegiatan; (c) Adanya harapan dan cita-cita; (d) Penghargaan dan penghormatan atas diri; (e) Adanya lingkungan yang baik; dan (f) Adanya kegiatan yang menarik.

\section{Bentuk-Bentuk Motivasi Belajar}

Dalam proses interaksi belajar mengajar, baik motivasi intrinsik maupun motivasi ekstrinsik diperlukan untuk mendorong siswa agar tekun melakukan aktifitas belajar. Motivasi ekstrinsik sangat diperlukan bila diantara siswa kurang berminat untuk mengikuti pelajaran dalam jangka waktu tertentu, peran motivasi ekstrinsik cukup besar untuk membimbing siswa dalam belajar. Hal ini perlu disadari guru, untuk itu seorang guru bisaanya memanfaatkan motivasi ekstrinsik untuk membangkitkan minat siswa agar lebih bergairah belajar, meski terkadang tidak tepat. Ada beberapa bentuk dan cara untuk menumbuhkan minat belajar siswa di sekolah, untuk itu rumusan yang dikemukakan Sardiman (2008: 92-95), perlu dipahami sebagai berikut, yaitu: (a) Memberi Angka; (b) Hadiah; (c) Saingan/Kompetisi; (d) EgoInvolement; (e) Memberi Ulangan; (f) Mengetahui Hasil; (g) Ujian; (h) Hukuman; (i) Hasrat untuk Belajar; (j) Minat; dan (k) Tujuan yang diakui.

Rumusan tujuan yang diakui dan diterima baik oleh siswa akan merupakan alat motivasi yang sangat penting sebab dengan memahami tujuan yang harus dicapai karena dirasakan sangat berguna dan menguntungkan, maka timbul gairah untuk belajar.

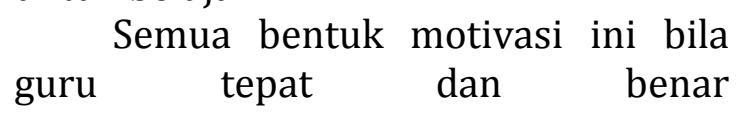

mempergunakannya, maka siswa akan termotivasi untuk belajar konteksnya dengan motivasi ekstrinsik, maka motivasi ini sangat erat hubungannya dengan kebutuhan siswa, siswa belajar karena ingin mendapatkan prestasi belajar yang tinggi.

\section{Faktor-Faktor Yang Mempengaruhi Motivasi Belajar}

Motivasi merupakan dorongan dan kekuatan dalam diri seseorang untuk melakukan tujuan tertentu yang ingin dicapainya. Yang dimaksud tujuan adalah sesuatu yang berada di luar diri manusia sehingga kegiatan manusia lebih terarah karena seseorang akan berusaha lebih semangat dan giat dalam berbuat sesuatu.

Konsep motivasi yang berhubungan dengan tingkah laku seseorang dapat deklasifikasikan sebagai berikut: (a) Seseorang senang terhadap sesuatu apabila ia dapat mempertahankan rasa senangnya maka termotivasi untuk melakukan kegiatan; dan (b) Apabila seseorang merasa yakin mampu menghadapi tantangan maka biasanya orang tersebut terdorong malakukan kegiatan tersebut.

Alkinson mengemukakan bahwa kecenderungan sukses ditentukan oleh motivasi, peluang, serta intensif. Begitu pula sebaliknya dengan kecenderungan untuk gagal. Motivasi dipengruhi oleh keadaan emosi seseorang. Guru dapat memberikan motivasi siswa dengan melihat seasana emosional siswa tersebut (Uno, 2008: 8).

Selanjutnya, Mulyasa (2007: 6263) mengemukakan ada beberapa faktor yang mempengaruhi motivaasi balajar yang dapat digunakan guru untuk memberikan stimulus siswa agart produktif dalam belajar antara lain: (a) Peserta didik akan belajar lebih giat apabila topik yang dipelajari menarik, dan berguna bagi dirinya; (b) Tujuan 
pembelajaran harus disusun dengan jelas dan diinformasikan kepada peserta sehingga mereka mengetahui tujuan belajar; (c) Peserta didik harus selalu diberi tahu tentang kompetensi, dan hasil belajarnya; (d) Pemberian pujian dan hadiah lebih baik dari pada hukuman, namun sewaktu-waktu hukuman juga diperlukan; (e) Manfaatkan sikap, cita-cita, rasa ingin tahu, dan ambisi peserta didik; (f) Usahakan untuk memperhatikan perbedaan individual peserta didik; dan (g) Usahakan untuk memenuhi kebutuhan peserta didik dengan jalan memperhatikan kondisi fisik, memberikan rasa aman, menunjukkkan bahwa guru memperhatikan mereka, mengatur pengalaman belajar sedemikian rupa sehingga setiap peserta didik pernah memperoleh kepuasan dan penghargaan, serta mengarahkan pengalaman belajar ke arah keberhasilan, sehingga mencapai prestasi dan mempunyai kepercayaan diri.

\section{Pentingnya Motivasi belajar}

Para ahli berpendapat bahwa motivasi perilaku manusia berasal dari kekuatan mental umum, insting, dorongan, kebetulan, proses kognitif, dan interaksi. Perilaku yang penting bagi manusia adalah belajar dan bekerja. Dengan belajar, menimbulkan perubahan mental pada diri anak didik. Dengan bekerja, menghasilkan sesuatu yang bermanfaat bagi diri pelaku dan orang lain.

Motivasi belajar penting bagi anak didik dan guru. Bagi anak didik, pentingnya motivasi belajar adalah sebagai berikut (Dimyati \& Mujiono, 2009: 84-85): (a) Menyadarkan kedudukan pada awal belajar, proses, dan hasil akhir; (b) Menginformasikan tentang kekuatan usaha belajar; (c) Mengarahkan kegiatan belajar; (d) Membesarkan semangat belajar; dan (e)
Menyadarkan tentang adanya perjalanan belajar.

\section{Fungsi Motivasi Belajar}

Dari motivasi intrinsik maupun ekstrinsik sama-sama berfungsi sebagai pendorong, penggerak dan penyeleksi perbuatan, ketiganya menyatu dalam sikap terimplikasi dalam perbuatan maka peranan yang dimainkan oleh guru dalam mengendalikan fungsifungsi motivasi merupakan langkah yang akurat untuk menciptakan iklim yang kondusif bagi anak didik.

Dari uraian di atas jelaslah bahwa motivasi mendorong timbulnya kelakuan dan mempengaruhi serta mengubah kelakuan. Jadi, sehubungan dengan hal tersebut ada tiga fungsi motivasi antara lain : (a) Mendorong timbulnya kelakuan atau suatu perbuatan tanpa motivasi tidak akan timbul perbuatan, motivasi dalam hal ini merupakan motor penggerak dari setiap kegiatan yang akan dikerjakan, seperti belajar; (b) Sebagai pengarah, artinya mengarahkan perbuatan kepada pencapaian tujuan yang diinginkan atau yang dicapainya. Dengan demikian motivasi dapat memberikan arah dan kegiatan yang harus dikerjakan sesuai dengan rumusan tujuannya; dan (c) Sebagai penggerak, yaitu menentukan perbuatan-perbuatan apa yang harus dikerjakan yang serasi guna mencapai tujuan, dengan menyisihkan perbuatanperbuatan yang tidak bermanfaat bagi tujuan tersebut (Hamalik, 2008: 161).

Menurut Uno (2008: 27-28) beberapa fungsi atau guna motivasi dalam belajar antara lain: (a) Motivasi dapat menentukan penguatan belajar; (b) Motivasi pada dasarnya dapat membantu dalam memahami dan menjelaskan perilaku individu, termasuk perilaku individu yang sedang belajar. Dan motivasi dapat berperan dalam penguatan belajar apabila 
seorang anak yang belajar dihadapkan pada suatu masalah yang memerlukan pemecahan,dan hanya dapat dipecahkan berkat bantuan hal-hal yang pernah dilaluinya. Dan sebagai seorang guru perlu memahami suasana itu, agar dapat membantu siswa dalam memilih faktor-faktor atau keadaan yang ada dalam lingkungan siswa sebagai bahan penguat belajar. Hal itu tidak cukup dengan memberitahukan sumbersumber yang harus dipelajari.melainkan yang lebih penting adalah mengaitkan isi pelajaran dengan perangkat apapun yang berada paling dekat dengan siswa di lingkungannya; (c) Dapat memperjelas tujuan belajar. Peran motivasi dalam memperjelas tujuan belajar erat kaitannya dengan kemaknaan belajar. Anak akan tertarik untuk belajar sesuatu, jika yang dipelajari itu sedikitnya sudah dapat diketahui atau dinikmati manfaatnya bagi siswa; dan (d) Motivasi dapat menentukan ketekunan belajar. Seorang anak yang telah termotivasi untuk belajar sesuatu, akan berusaha mempelajarinya dengan baik dan tekun, dengan harapan memperoleh hasil yang baik. Dalam hal ini, tampak bahwa motivasi untuk belajar menyebabkan seseorang tekun belajar.

\section{METODE}

\section{Jenis penelitian dan pendekatan}

Jenis penelitian ini adalah kualitatif lapangan (grounded), dengan menggunakan pendekatan dari penelitian ini adalah descriptive qualitative - fenomenology. Sebagai tambahan, peneliti menggunakan descriptif yaitu mengumpulkan data sebanyak-banyaknya mengenai kompetensi guru dalam meningkatkan motivasi belajar (Arikunto, 2006: 108).

Menurut Moleong deskriptif yaitu data yang dikumpulkan adalah berupa kata-kata, gambar-gambar dan bukan angka-angka. Dengan demikian, laporan penelitian berisi kutipan-kutipan data untuk memberi gambaran penyajian laporan tersebut (Moleong, 2005: 11).

Data tersebut mungkin berasal dari naskah wawancara, catatan lapangan, foto, video tape, dokumen pribadi, catatan atau memo, dan dokumen resmi lainnya.

\section{HASIL DAN PEMBAHASAN}

Pada bagian ini penulis mencoba menguraikan sekaligus melakukan pembahasan dan analisa terhadap kompetensi guru dalam meningkatkan motivasi belajar siswa di MTsN Pekan Heran Kecamatan Rengat Barat, Kab.Indragiri Hulu, tentunya pembahasan dan analisa ini penulis lakukan dari sudut pandang penulis berdasarkan pada fakta dan realita yang ada di lapangan dan juga beberapa teori yang ada.

\section{Motivasi Belajar Siswa Di MTsN Pekan Heran}

Motivasi adalah suatu perubahan energi dengan timbulnya efek dan reaksi untuk mencapai tujuan (Hamalik, 2008: 158). Jadi motivasi belajar adalah kekuatan atau tenaga yang dapat memberikan dorongan kepada kegiatan belajar murid.

Perubahan energi dalam diri seseorang itu berbentuk suatu aktifitas nyata berupa kegiatan fisik, karena seseorang mempunyai tujuan tertentu dari aktifitasnya. Maka seseorang mempunyai motivasi yang kuat untuk mencapainya dengan segala upaya yang dapat dilakukan.

Dalam proses belajar, motivasi sangat diperlukan sebab seseorang yang tidak mempunyai motivasi dalam belajar, tidak akan mungkin melakukan atifitas belajar. Dalam kegiatan belajar, maka motivasi belajar adalah 
keseluruhan daya penggerak di dalam diri siswa yang menimbulkan kegiatan belajar, yang menjamin kelangsungan dari kegiatan belajar dan yang memberikan arah pada kegiatan belajar, sehingga tujuan yang dikehendaki oleh subyek belajar itu dapat tercapai (Sardiman, 2008: 75).

Seseorang yang melakukan aktifitas belajar secara terus menerus tanpa motivasi dari luar dirinya merupakan motivasi intrinsik yang sangat penting dalam aktifitas belajar. Namun seseorang yang tidak mempunyai keinginan untuk belajar dalam dirinya merupakan motivasi ekstinsik yang diharapkan.

Oleh karena itu motivasi ekstinsik diperlukan bila motivasi intinsik tidak ada dalam diri seseorang sebagai subyek belajar.

Motivasi belajar siswa di MTsN Pekan Heran cukup baik karena dipengaruhi dengan adanya lingkungan yang baik. Hal ini terbukti dengan banyaknya para siswa yang cukup antusias dalam mengikuti kegiatankegiatan yang diadakan sekolah, tetapi guru di MTsN Pekan Heran tidak hentihentinya berusaha meningkatkan motivasi belajar siswa, hal ini dilakukan oleh guru agar dalam proses belajar mengajar dapat berjalan maksimal. Sehingga siswa di MTsN Pekan Heran ini termotivasi dan merasa nyaman dalam mengikuti pelajaran yang disampaikan oleh guru.

Oleh karena itu, motivasi belajar siswa di MTsN Pekan Heran perlu ditingkatkan lagi, hal ini bertujuan untuk mencapai keberhasilan proses belajar mengajar secara optimal dalam mewujudkan pembentukan manusia muslim yang mampu mengamalkan ajaran agama Islam dalam kehidupan sehari- hari dan dapat dijadikan sebagai pedoman hidup sesuai dengan visi dan misi dari MTsN Pekan Heran itu sendiri.

\section{Kompetensi Guru Dalam Meningkatkan Motivasi Belajar Siswa Di MTsN Pekan Heran Kecamatan Rengat Barat Indragiri Hulu}

Kompetensi guru adalah seperangkat pegetahuan, keterampilan, dan perilaku yang harus dimiliki, dihayati, dikuasai, dan diwujudkan oleh guru dalam melaksanakan tugas keprofesionalannya. KepmenKemenag No.045/U/2002 menyebutkan kompetensi sebagai seperangkat tindakan cerdas dan penuh tanggung jawab dalam melaksanakan tugas-tugas sesuai dengan pekerjaan tertentu (Sarimaya, 2008: 17).

Dalam undang-undang No:14 tahun 2005 tentang guru dan dosen bab IV pasal 10 ditegaskan bahwa untuk mampu melaksanakan tugas profesionalnya dengan baik, seorang guru harus memiliki empat kompetensi inti yakni : kompetensi pedagogik, kompetensi kepribadian, kompetensi sosial dan kompetensi profesional (Gintings, 2008: 12).

Jadi kompetensi guru dapat dimaknai sebagai kebulatan pengetahuan, keterampilan dan sikap yang berwujud tindakan cerdas dan penuh tanggung jawab dalam melaksanakan tugas sebagai agen pembelajaran Motivasi Belajar Siswa.

Kompetensi guru merupakan kemampuan dasar yang harus dimiliki oleh seorang guru yang pengaruhnya sangat besar sekali terhadap motivasi belajar siswa. Dimana siswa dalam mengaplikasikan dirinya yang tidak semuanya baik, ada yang setengahsetengah. Oleh karena itu dibutuhkan perfomence seorang guru yang berkompeten baik itu yang dapat dijadikan suri tauladan didalam kelas maupun diluar kelas, karena ada kecendrungan bahwa seorang siswa akan memiliki dan melihat gurunya. 
Fungsi kompetensi guru tidak hanya sebagai indicator keberhasilan terhadap proses belajar mengajar, akan tetapi juga sebagai kualitas institusi pendidikan. Disamping itu motivasi belajar juga mampu berguna sebagai Feed Back (umpan balik) bagi guru dalam melaksanakan proses belajar mengajar sehingga dapat menentukan tujuan pendidikan, dengan demikian pendidikan di sekolah akan maju mendorong siswa untuk meningkatkan belajarnya, apabila disekolah terbentuk kompetensi guru. Karena kompetensi guru disini di maksud sebagai control dan pusat perhatian anak dalam kehidupan belajar di sekolah. Maka guru harus berusaha dengan sungguhsungguh dan berkomitmen dalam meningkatkan kompetensi dalam mengajarnya.

Di MTsN Pekan Heran sudah 80\% dari beberapa guru mengambil langkah untuk meningkatkan kompetensinya dan untuk mendukung itu semua sekolah biasanya melaksanakan workshop/pelatihan untuk guru secara internal disekolah dan tidak lupa melaksanakan in house training atau pendamping bagi guru-guru dalam PBM. Itu semua dilakukan untuk menunjang dan meningkatkan kualitas guru.

MTsN Pekan Heran dengan berbagai fasilitas dan sarana penunjang yang cukup memadai dapat dikatakan sebagai salah satu lembaga yang mempunyai kompetensi guru cukup baik. Hal ini dapat terlihat dari beberapa hal, antara lain, guru yang mengajar adalah mayoritas lulusan perguruan tinggi, adanya fasilitas yang memadai bagi para guru sehingga dapat lebih leluasa untuk melakukan kegiatan belajar mengajar secara maksimal dimana sekolah memberi kebebasan memilih stategi, metode dan tehnik pembelajaran dan pengajaran yang paling efektif, sesuai dengan karakteristik mata pelajaran, dan mata pelajaran yang diajarkan oleh guru sesuai dengan latar belakang pendidikan guru tersebut.

Kompetensi guru dalam meningkatkan motivasi belajar di MTsN Pekan Heran yakni meningkatkan minat siswa kearah yang benar, menimbulkan sikap yang baik, disinilah letak yang positif agar dalam bersekolah tidak merasa bosan, disamping itu juga guru harus kreatif, mengatur proses pembelajaran dan mengatur pengalaman belajar serta kegiatankegiatan yang berhubungan dengannya.

Adapun maksud dari menumbuhkan semangat belajar di sini adalah bagaimana siswa agar selalu mempunyai keinginan untuk belajar. Ada beberapa cara yang dilakukan guru di MTsN Pekan Heran untuk menumbuhkan minat belajar yaitu: (a) Memberikan hadiah; (b) Melakukan pendekatan; (c) Membesarkan semangat belajar; (d) Mengarahkan kegiatan belajar; dan (e) Memberikan pujian.

Namun penulis juga tidak menafikan masih banyak hal yang harus diperbaiki dalam kompetensi guru tersebut, antara lain meningkatkan kapabilitas dan profesionalisme guru, pemanfaatan berbagai macan sarana penunjang secara maksimal. Tapi dapat dikatakan sudah baik dan memang sudah mendekati ideal. Hal ini bisa diliat dari antusiasme dan semangat para siswa dalam mengikuti proses pelajaran yang disampaikan oleh guru, tentu hal ini adalah perubahan dan kemajuan yang bisa dikatakan sebagai hal yang cukup luar biasa, sebab sebagai target/tujuan dari kompetensi guru sudah tercapai, yaitu para siswa meningkatkan minat, dan selalu mempunyai keinginan untuk belajar. 


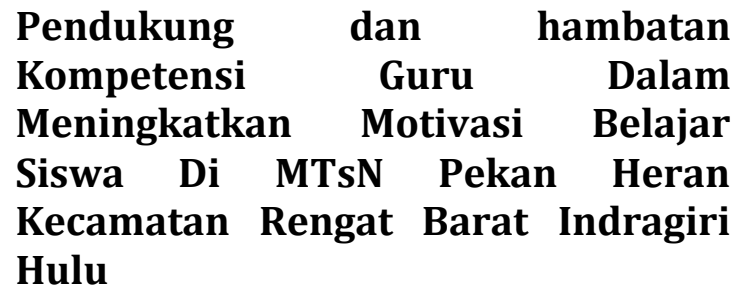

Adapun hal-hal yang mendukung kompetensi guru dalam meningkatkan motivasi belajar siswa di MTsN Pekan Heran Kecamatan Rengat Barat Indragiri Hulu, yaitu: (a) Guru yang mampu melaksanakan kebijakan; (b) Diadakannya pelatihan-pelatihan pengembangan diri guru; (c) Keakraban antara guru dan siswa; (d) Musyawaroh antar guru; (e) Desain kurikulum; (f) Metode-metode yang digunakan oleh guru; (g) Lingkungan Masyarakat; dan (h) Siswa.

Sedangkan hal-hal yang menghambat kompetensi guru dalam meningkatkan motivasi belajar siswa di MTsN Pekan Heran Kecamatan Rengat Barat Indragiri Hulu, yaitu: (a) Kurang memahaminya seorang guru terhadap siswanya, atau sebaliknya; (b) Penerapan dari guru yang kurang efektif; (c) Faktor pengendalian dalam artian anak yang aktif tapi liar; (d) Kurang menariknya materi yang di sampaikan; (e) Faktor keluarga; (f) Kurang rasa ingin tahu siswa terhadap materi yang di ajarkan; dan (g) Guru merasa cukup dengan pengetahuan dan kualifikasi yang dimiliki.

\section{SIMPULAN}

Berdasarkan data yang diperoleh oleh peneliti baik melalui interview, observasi, dan dokumentasi tentang Kompetensi Guru Dalam Meningkatkan Motivasi Belajar (Study Kasus Pada MTsN Pekan Heran Kecamatan Rengat Barat,Indragiri Hulu) maka dapat diambil sebuah kesimpulan bahwa: Pertama, motivasi belajar siswa di MTsN Pekan Heran cukup baik karena dipengaruhi dengan adanya lingkungan yang baik. Hal ini terbukti dengan cukup antusiasnya siswa dalam mengikuti kegiatan- kegiatan yang diadakan sekolah Untuk menumbuhkan semangat belajar, ada beberapa cara yang dilakukan guru di MTsN Pekan Heran untuk menumbuhkan minat belajar yaitu: (a) Memberikan hadiah; (b) Melakukan pendekatan; (c) Membesarkan semangat belajar; (d) Mengarahkan kegiatan belajar; dan (e) Memberikan pujian.

Kedua, di MTsN Pekan Heran sudah $80 \%$ dari beberapa guru mengambil langkah untuk meningkatkan kompetensinya dan untuk mendukung itu semua sekolah biasanya melaksanakan workshop/pelatihan untuk guru secara internal disekolah dan tidak lupa melaksanakan in house training atau pendamping bagi guru-guru dalam PBM. Itu semua dilakukan untuk menunjang dan meningkatkan kualitas guru. Disamping itu, hal ini dapat terlihat dari beberapa hal, antara lain, guru yang mengajar adalah mayoritas lulusan perguruan tinggi, adanya fasilitas yang memadai bagi para guru sehingga dapat lebih leluasa untuk melakukan kegiatan belajar mengajar secara maksimal dimana sekolah memberi kebebasan memilih stategi, metode dan tehnik pembelajaran dan pengajaran yang paling efektif, sesuai dengan karakteristik mata pelajaran, dan mata pelajaran yang diajarkan oleh guru sesuai dengan latar belakang pendidikan guru tersebut.

\section{DAFTAR RUJUKAN}

Al Imam Abu Abdullah Muhammad bin Ismail. Shahih Bukhori Juz I. Terjemah Oleh Ahmad Sunarto, dkk.1992. Semarang. CV Asy Syifa'.

Arifin, Muzayyin. 2008. Kapita Selekta Pendidikan Islam. Jakarta : PT Bumi Aksara. 
Arikunto, Suharsimi. 2006. Prosedur Penelitian Suatu Pendekatan Praktek. Jakarta : PT Rineka Cipta.

Departemen Agama RI. 1996. Al-Qur an Al-Karim dan Terjemah. Semarang : PT Karya Toha Putra.

Dimyati dan Mujiono. 2009. Belajar dan Pembelajaran. Jakarta: PT Rineka Cipta.

Djamaroh, Saiful Bahri. 1994. Prestasi Belajar dan Kompetensi Guru. Usaha Nasional Surabaya.

Gintings, Abdorrakhman. 2008. Esensi Praktis Belajar dan Pembelajaran. Bandung: Humaniora.

Hamalik, Oemar. 2008. Proses Belajar Mengajar. Jakarta : PT Bumi Aksara.

Moleong, Lexy. 2005. Metode Penelitian Kualitatif. Bandung : PT Remaja Rosdakarya.

Muchtar, Heri Jauhar. 2005. Fikih Pendidikan. Bandung : Rosda Remaja.

Mulyasa, E. 2007. Standar Kompetensi dan Sertifikasi Guru. Bandung : PT Remaja Rosdakarya.
Rosadi, Khoiron. 2002. Pendidikan Profetik. Yogyakarta : PustakaPelajar.

Samsudin, Abin dan Nandang Budiman. 2006. Profesi Keguruan. Jakarta : Universitas Terbuka.

Sardiman, A.M. 2008. Interaksi dan Motvasi Belajar Mengajar. Jakarta : PT Raja Grafindo Persada.

Sarimaya, Farida. 2008. Setifikasi Guru. Bandung: Yrama Widya.

Sugiyono. 2008. Memahami Penelitian Kualitatif. Bandung. CV Alfabeta.

Surya, M. Dkk. 2007. Kapita Selekta Kependidikan SD. Jakarta : Universitas Terbuka.

Uno, Hamzah B. 2007. Profesi Kependidikan. Jakarta : PT Bumi Aksara.

Uno, Hamzah.B. 2008. Teori Motivasi dan Pengukurannya. Jakarta : PT Bumi Aksara.

Usman, Moh. Uzer. 2009. Menjadi Guru Profesional. Bandung : PT Remaja Rosdakarya. 